\title{
DDT exposure of frogs: a case study from Limpopo Province, South Africa
}

Ignatius M Viljoen a,b,", Riana Bornman ${ }^{\mathrm{c}}$, Hindrik Bouwman ${ }^{\mathrm{a}}$

${ }^{a}$ Research Unit: Environmental Sciences and Management, North-West University, Private Bag X6001, Potchefstroom 2520, South Africa.

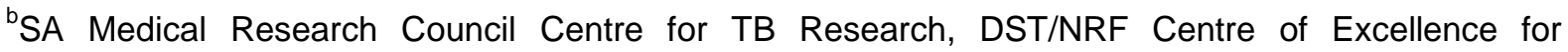
Biomedical Tuberculosis Research, Division of Molecular Biology and Human Genetics, Faculty of Medicine and Health Sciences, Stellenbosch University, Francie van Zijl Drive, Tygerberg, 7505, South Africa.

${ }^{\mathrm{C}}$ SA Medical Research Council Centre \& University of Pretoria Centre for Sustainable Malaria Control (MRC \& UP CSMC), School of Health, Systems and Public Health, University of Pretoria, Pretoria, 0028, South Africa.

${ }^{*}$ Corresponding author at:

Ignatius M Viljoen ${ }^{1}$

e-mail: iggie@shawu.co.za

Tel: $+27(0) 829206281$

\section{Highlights}

- Contaminants is suspected to play a part in amphibian declines worldwide

- No POPs data in frogs from areas where DDT is used for malaria control

- Quantifiable DDT was found in frog fat from an area where DDT is used

- No testicular oocytes were found in any frog

- Significant asymmetric testicular morphology in frogs from the sprayed area

\section{Abstract}

Amphibians are globally under pressure with environmental contaminants contributing to this. Despite caution aired more than 80 years ago of threats posed to amphibians by DDT spraying for disease vector control, no data have been published on concentrations or effects of DDT contamination in frogs from areas where DDT is actively sprayed to control the insect vectors of malaria. In this study, we sampled fat bodies of Xenopus laevis and $X$. muelleri naturally occurring in an area where indoor residual spraying of DDT is employed and from adjacent, non-sprayed, areas. $\Sigma D D T$ concentrations ranged between $\angle \mathrm{LOQ}$ and $280 \mathrm{ng} / \mathrm{g} \mathrm{ww}$ (wet weight) from the non-sprayed area, and 5.5 to $910 \mathrm{ng} / \mathrm{g} \mathrm{ww}$ from the sprayed area, but statistical significance could not be shown. We observed significant asymmetric testicular morphology in frogs from the sprayed area, possibly due to endocrine disruption by compounds such as the DDTs. A previous study from the same area found very high concentrations of DDT in the eggs of the Grey Heron Ardea cinerea. This suggests that the DDT we found in frogs may have contributed to DDT loadings higher in the food

\footnotetext{
${ }^{1}$ Present address: SA Medical Research Council Centre for TB Research, DST/NRF Centre of Excellence for Biomedical Tuberculosis Research, Division of Molecular Biology and Human Genetics, Faculty of Medicine and Health Sciences, Stellenbosch University, Francie van Zijl Drive, Tygerberg, 7505, South Africa.
} 
web. These findings, combined with other studies from this area, support the need to reduce and eventually move away from DDT in malaria control safely and sustainably.

Key words: Xenopus, DDT, South Africa, Amphibia, Endocrine disruptive compounds, Fluctuating asymmetry

\section{Introduction}

With amphibians globally under pressure (Blaustein et al. 2011; Collins and Storfer 2003), chemical contaminants may be contributing to their decline (Carey and Bryant 1995). DDT has been used since the late 1940's to control mosquitoes and other disease vectors in South Africa, but DDT use is now globally restricted by the Stockholm Convention (Bouwman 2003; van Dyk et al. 2010). To achieve control, DDT is applied at $2 \mathrm{~g} / \mathrm{m}^{2}$ on indoor walls and other surfaces of residences for malaria control, thereby interrupting transmission of the parasite by the vector. From decades of use, residues of DDT associated with malaria control have accumulated in the environment and in human and animal tissues. DDT residues have been measured in human milk (Bouwman et al. 1990, Bouwman et al. 2006, Sereda et al. 2009) and blood (Aneck-Hahn et al., 2007, Whitworth et al., 2014; Gaspar et al. 2015) from inhabitants to the east of Thohoyandou, Vhembe District, Limpopo Province (Fig. 1). Terrestrial and aquatic bird eggs from the same area contained high concentrations of DDT; e.g. Grey Heron Ardea cinerea eggs had the highest LDDT concentrations reported this century for any aquatic bird worldwide (Bouwman et al. 2013). No breeding colonies of water birds could be found in the sprayed areas between Thohoyandou and the Kruger National Park (KNP), despite repeated and extensive searches. It was speculated that reproductive failure might have caused local disappearance, similar to what was found in Canada after similar concentrations of DDT occurred in Great Blue Heron eggs Ardea herodias (Laporte 1982). Eggshells of the terrestrially feeding Cattle Egret Bubulcus ibis from the DDT spayed area were significantly thinner and had significantly higher concentrations of DDT (Bouwman et al. 2013). Fish from the Luvuvhu River contained DDT and the levels were particularly higher inside the sprayed area (Barnhoorn et al. 2009). Very high concentrations of $\Sigma$ DDT (mean 4 249, max 22000 $\mathrm{ng} / \mathrm{g}$ lipid) were found in Tigerfish Hydrocynus vittatus from the Luvuvhu River inside the KNP, downstream of the DDT-sprayed area (Gerber et al. 2016).

Food items of the Grey Heron (an aquatic predator) include fish and amphibians (Hockey et al. 2005). Although there are published studies on DDT in fish from sprayed areas (e.g. Barnhoorn et al. 2009; Bouwman et al. 1990), there is very little data from Africa about DDT in amphibians. DDT residues were detected in frogs from Somalia in relation to a pesticide spill (Lambert 1997), and DDT was quantified in frogs from the Rift Valley (Lincer et al. 1981). With the high concentrations of DDT found in fish and bird eggs from Limpopo, the residue concentrations in frogs should be investigated, given the sensitivity of amphibians to toxic and endocrine disrupting (ED) pollutants (Carey and Bryant 1995) and as a possible vector of DDT to higher trophic level animals. It is interesting to note that the first caution about the potential impacts on amphibians of DDT used for malaria control was published in Science in 1944 (Ellis et al. 1944). However, more than 80 years later, we could find no reference to DDT in frogs from any area where DDT is actively used for malaria control. This study aimed at quantifying and interpreting DDT and metabolite concentrations and somatic 
parameters in frogs from an area where DDT is currently used for malaria vector control compared with a reference area where DDT is not used.

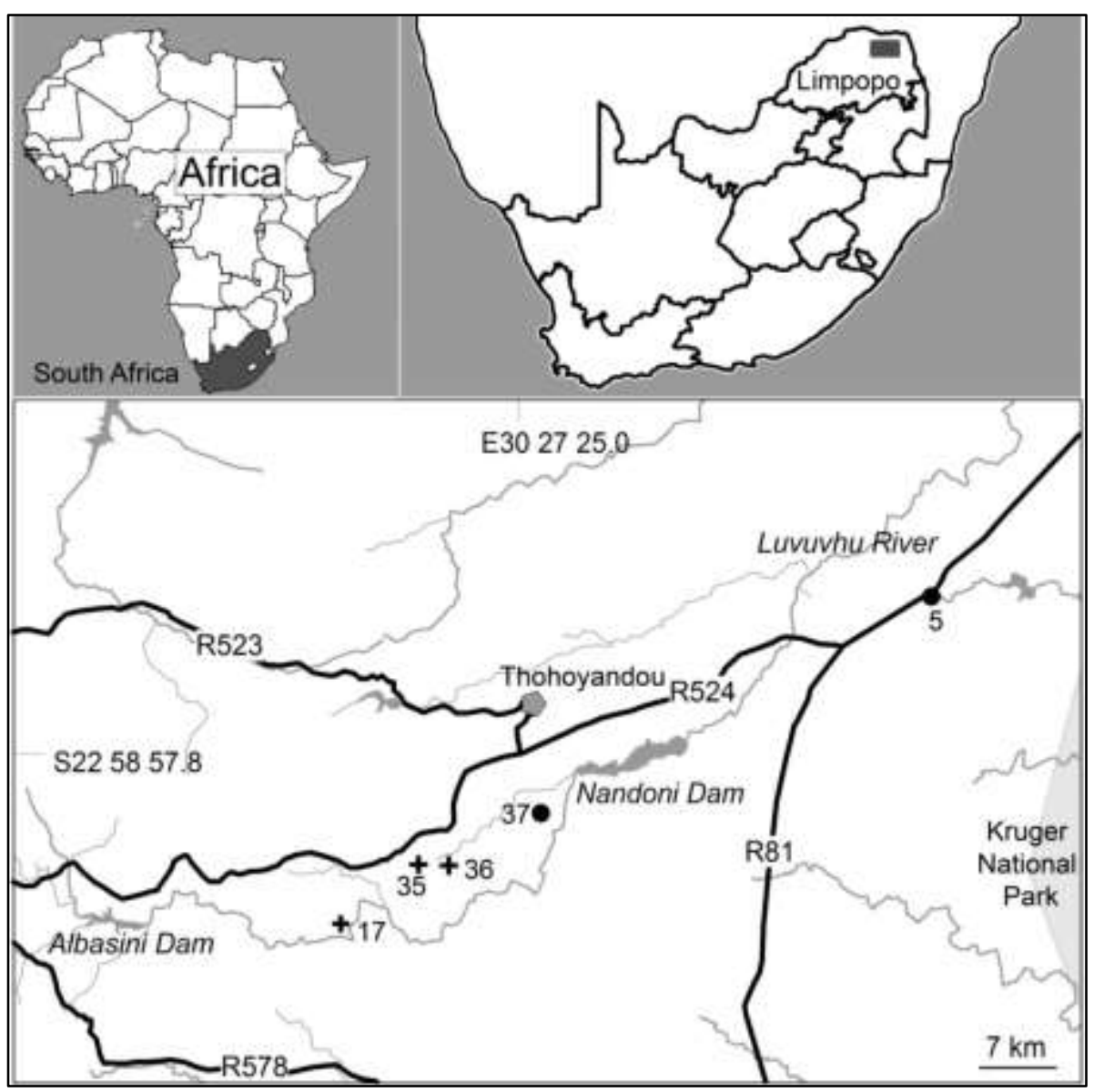

Figure 1: Map of the study area with sample locations indicated. The DDT-sprayed area is east of the city of Thohoyandou. + Sites in reference area $\cdot$ Sites in DDT-sprayed area

\section{Materials and methods}

\subsection{Ethical clearance and permits}

This study was approved by the North-West University Ethics Committee (NWU0053-08-A6). Permission for collection was granted by the Department of Economic Development, Environment and Tourism: Limpopo Province (CPM001958). This permit allowed for the collection of no more than 50 specimens per species from the study area.

\subsection{Sampling}

We collected African Clawed Frogs Xenopus laevis and Müllers Platanna Xenopus muelleri from ponds and small dams in Limpopo Province where DDT is used for malaria control (Fig. 1) and sampled their fat bodies. The collection campaign lasted 10 days in December 2009 using baited funnel traps, deploying three to four traps per site at multiple sites per night for 12 hours per trap. The traps were baited in the afternoon and left overnight to be collected the following morning. The frogs were transported in containers with water 
from their habitat back to base camp. Each frog was anaesthetised in an MS 222 (tricaine methanesulfonate) solution, weighed, and measured. Testes dimensions were measured in the field on fresh frogs as measurement units $(\mathrm{mu})$ using a graduated ocular in a dissection microscope - real scale measurement was not possible at the time. Fat bodies were collected from each frog, weighed, and frozen in foil (foil was prepared by washing three times respectively with ethanol and hexane).

\subsection{Chemical analyses}

Of the 38 frogs sampled, 22 were analysed for $p, p^{\prime}$-DDT, o, $p^{\prime}-\mathrm{DDT}, p, p^{\prime}-\mathrm{DDE}, o, p^{\prime}-$ DDE, $p, p^{\prime}-\mathrm{DDD}$, and $o, p^{\prime}$-DDD. DDT concentrations were analysed by an ISO 17025 accredited laboratory (Food and Drug Assurance Laboratories, Pretoria) using the European standard method NF-EN-1528 in fatty foodstuffs, using GC-MS. A C18 cartridge was used to extract DDT and its metabolites, followed by a florisil cartridge clean up according to Bordet et al. (2002). The analytes were eluted with a petroleum ether - diethyl ether mixture. Since Aldrin was not detected in unfortified samples, it was used as an internal standard. Quantification was via fortified calibration curves in matrix; the correlation coefficient was 0.99. Limits of detection (LOD) was three times the standard deviation of background noise, and limits of quantification (LOQ) was three times the LOD. The LOQs were $15 \mathrm{ng} / \mathrm{g}$ wet weight $(\mathrm{ww})$ for $p, p^{\prime}-\mathrm{DDT}, 10 \mathrm{ng} / \mathrm{g} w \mathrm{w}$ for $p, p^{\prime}$-DDE and $o, p^{\prime}-\mathrm{DDT}, 5 \mathrm{ng} / \mathrm{g}$ for $w \mathrm{w} p, p^{\prime}-\mathrm{DDD}$ and $o, p^{\prime}-\mathrm{DDD}$, and $1 \mathrm{ng} / \mathrm{g} \mathrm{ww}$ for $o, p^{\prime}-\mathrm{DDE}$. Means were calculated for positive samples only.

\subsection{Histological preparations}

To assess possible endocrine disruption, histological preparations were made of testes from eight randomly selected male frogs (four from DDT-sprayed and four from nonsprayed areas), and screened for testicular oocytes. The sample from the DDT-sprayed area consisted of two $X$. muelleri from two different sites, and two $X$. laevis from one site. The sample for the non-DDT-sprayed area consisted of one $X$. muelleri and three $X$. laevis from three different sites. Preparation of the histology slides was adapted from Weldon (2005) and Jooste et al. (2005). Serial sections were made longitudinally at $6 \mu \mathrm{m}$ intervals and then stretched and affixed to microscope slides using Mayer's albumen and a heating plate (45 $\left.{ }^{\circ} \mathrm{C}\right)$. The slides were then dried overnight at $35^{\circ} \mathrm{C}$. The slides were coloured with Mayer's haematoxylin and eosin, and fixed. The fixed slides were inspected under a light microscope (Nikon YS100).

\subsection{Statistical analyses}

Statistical analyses and visual representation of results were done with GraphPad Prism Version 4 for Windows (GraphPad Software, Inc., CA, USA). Morphometric data were compared between the reference and study areas using two-way, unpaired, Mann Whitney non-parametric tests. Comparisons of the left and right testes within the reference or study areas were done with a paired T-test. 

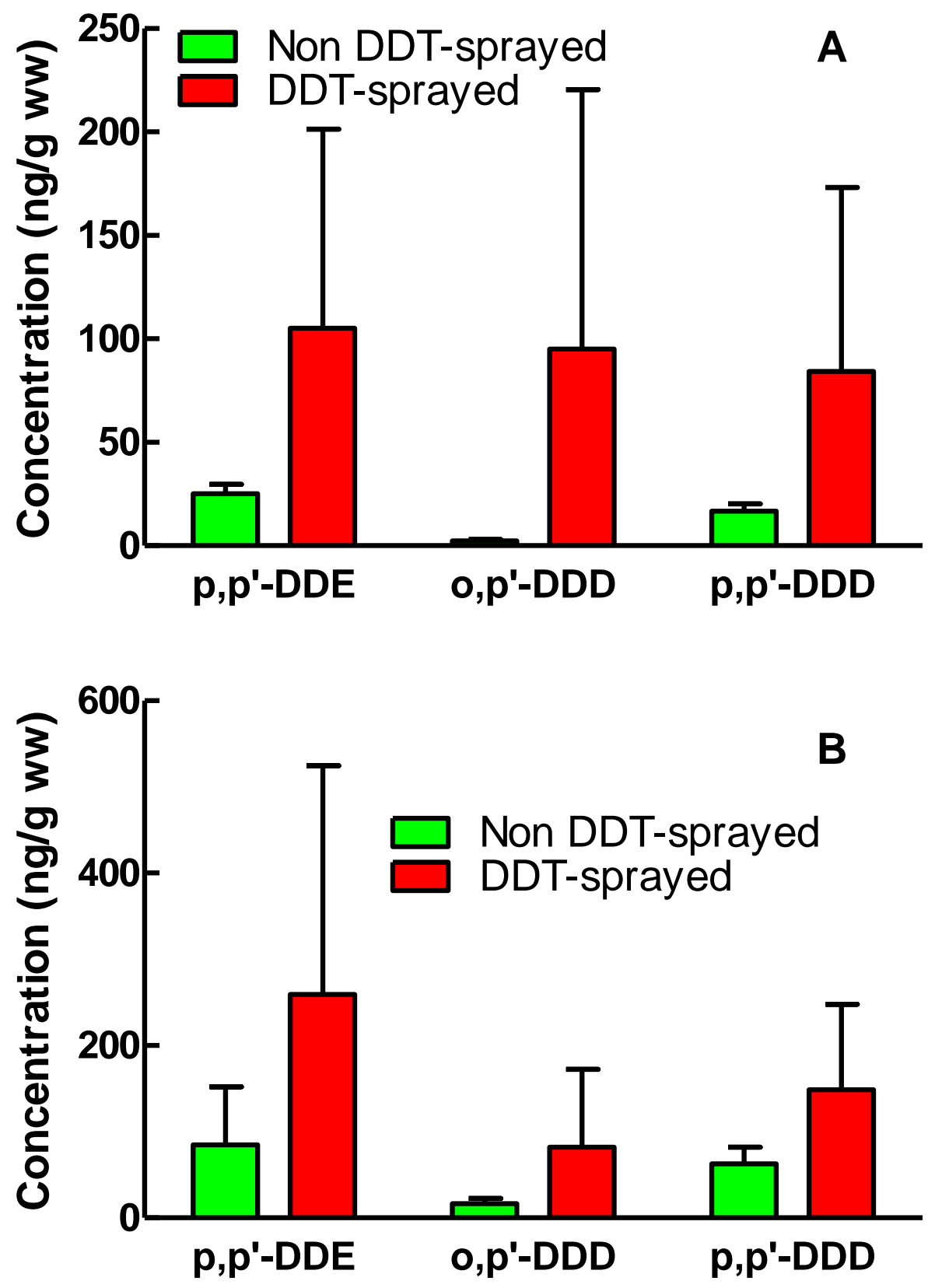

Figure 2: Means and standard deviations of $p, p^{\prime}-\mathrm{DDE}, o, p^{\prime}-\mathrm{DDD}$ and $p, p^{\prime}-\mathrm{DDD}$ in frog fat from the Limpopo Province. Due to low sample numbers, further statistical comparisons were not possible. A - Male frogs; $B$ Female frogs.

\section{Results}

Combined, we conducted 25 trap nights (multiple sites per night over 10 days) with approximately 2400 combined trap hours. The sites were located between 150-400 m away from the closest river, all of them flowing only sporadically after rains, except Site 17 that was $400 \mathrm{~m}$ away from the permanently flowing Luvuvhu River. Ten sites were visited with 
only five of these (Fig. 1) yielding Xenopus frogs. We collected 38 specimens of the two Xenopus species from both areas combined.

Individual results and means of residue concentrations are presented in Table 1. Neither $p, p^{\prime}$-DDT nor $o, p$ '-DDT could be quantified in any sample. All but one frog (no. 7 in Table 1) had quantifiable residues for at least one of the DDT metabolites. There were not enough data to conduct statistical comparisons on the residue concentrations. The differences in concentrations for male and female Xenopus species are graphically presented in Fig. 2.

Table 1: DDT concentrations (ng/g wet weight) in the fat bodies of Xenopus sp. caught in DDT-sprayed and nonDDT-sprayed areas. $o, p^{\prime}$-DDT and $p, p^{\prime}$-DDT was not quantifiable in any sample.

\begin{tabular}{|c|c|c|c|c|c|c|c|c|c|}
\hline Site & No. & Species & Sex & Area & $o, p$-DDE & $p, p$ '-DDE & $o, p$ '-DDD & $p, p$ '-DDD & 2DDT \\
\hline 36 & 5 & X. muelleri & male & $\begin{array}{c}\text { Non-DDT } \\
\text { sprayed } \\
\text { Non-DDT }\end{array}$ & $<\mathrm{LOQ}$ & 19.8 & 4.5 & 12.6 & 36.9 \\
\hline 36 & 6 & $X$. laevis & male & $\begin{array}{c}\text { sprayed } \\
\text { Non-DDT }\end{array}$ & $<L O Q$ & 12.1 & 1.3 & 5.7 & 19.1 \\
\hline 36 & 7 & $X$. muelleri & male & $\begin{array}{c}\text { sprayed } \\
\text { Non-DDT }\end{array}$ & $<L O Q$ & $<L O Q$ & $<L O Q$ & $<L O Q$ & $<L O Q$ \\
\hline 36 & 8 & $X$. laevis & male & $\begin{array}{c}\text { sprayed } \\
\text { Non-DDT }\end{array}$ & $<\mathrm{LOQ}$ & 15.6 & 1.3 & 22.6 & 39.5 \\
\hline 36 & 10 & $X$. laevis & male & $\begin{array}{l}\text { sprayed } \\
\text { Non-DDT }\end{array}$ & $<\mathrm{LOQ}$ & 21.9 & $<L O Q$ & 7.6 & 29.5 \\
\hline 36 & 12 & $X$. laevis & male & $\begin{array}{c}\text { sprayed } \\
\text { Non-DDT }\end{array}$ & $<L O Q$ & 42.0 & $<L O Q$ & 10.9 & 52.9 \\
\hline 36 & 13 & $X$. laevis & male & $\begin{array}{c}\text { sprayed } \\
\text { Non-DDT }\end{array}$ & $<\mathrm{LOQ}$ & 48.8 & 0.9 & 36.8 & 86.5 \\
\hline 36 & 16 & $X$. laevis & male & $\begin{array}{c}\text { sprayed } \\
\text { Non-DDT }\end{array}$ & $<\mathrm{LOQ}$ & 20.9 & 3.2 & 21.7 & 45.8 \\
\hline 35 & 21 & $X$. laevis & male & $\begin{array}{c}\text { sprayed } \\
\text { Non-DDT }\end{array}$ & $<\mathrm{LOQ}$ & 20.2 & 3.3 & 15.5 & 39.0 \\
\hline \multirow[t]{2}{*}{35} & 25 & $X$. muelleri & male & sprayed & $<\mathrm{LOQ}$ & $<\mathrm{LOQ}$ & $<\mathrm{LOQ}$ & 6.6 & 6.6 \\
\hline & & & & MEAN & & 25.2 & 2.4 & 15.6 & 39.5 \\
\hline 37 & 28 & X. laevis & male & DDT-sprayed & $<L O Q$ & 39.4 & 6.6 & 52.9 & 98.9 \\
\hline 37 & 30 & $X$. laevis & male & DDT-sprayed & $<\mathrm{LOQ}$ & $<L O Q$ & $<L O Q$ & 5.5 & 5.5 \\
\hline 37 & 35 & $X$. laevis & male & DDT-sprayed & $<\mathrm{LOQ}$ & 53.5 & $<L O Q$ & 25.6 & 79.1 \\
\hline 37 & 37 & X. muelleri & male & DDT-sprayed & $<L O Q$ & 80.6 & $<L O Q$ & 110.0 & 190.6 \\
\hline \multirow[t]{2}{*}{5} & 40 & X. muelleri & male & DDT-sprayed & $<\mathrm{LOQ}$ & 247.2 & 183.8 & 227.1 & 658.1 \\
\hline & & & & MEAN & & 105.2 & 95.2 & 84.2 & 206.4 \\
\hline 35 & 20 & $X$. laevis & female & $\begin{array}{l}\text { Non-DDT } \\
\text { sprayed } \\
\text { Non-DDT }\end{array}$ & 18.9 & 17.7 & 22.3 & 42.5 & 101.4 \\
\hline 35 & 24 & X. laevis & female & $\begin{array}{c}\text { sprayed } \\
\text { Non-DDT }\end{array}$ & $<\mathrm{LOQ}$ & 152.0 & 23.1 & 102 & 277.1 \\
\hline 35 & 26 & X. muelleri & female & $\begin{array}{l}\text { sprayed } \\
\text { Non-DDT }\end{array}$ & $<L O Q$ & 119.2 & 4.8 & 43.1 & 167.1 \\
\hline \multirow[t]{2}{*}{17} & 4 & X. muelleri & female & sprayed & $<\mathrm{LOQ}$ & $<\mathrm{LOQ}$ & 0.8 & 11.8 & 12.6 \\
\hline & & & & MEAN & 18.9 & 96.3 & 12.8 & 49.9 & 139.6 \\
\hline 37 & 33 & $X$. laevis & female & DDT-sprayed & 46.3 & 477.1 & 145.9 & 245.1 & 914.4 \\
\hline 37 & 39 & $X$. laevis & female & DDT-sprayed & $<\mathrm{LOQ}$ & 70.9 & 18.3 & 47.8 & 137.0 \\
\hline \multirow[t]{2}{*}{5} & 41 & X. muelleri & female & DDT-sprayed & $<\mathrm{LOQ}$ & $<\mathrm{LOQ}$ & $<\mathrm{LOQ}$ & 154.8 & 154.8 \\
\hline & & & & MEAN & 46.3 & 274.0 & 82.1 & 149.2 & 402.1 \\
\hline
\end{tabular}

Statistical analysis could only be done with the morphometrics of male $X$. laevis as there was not enough $X$. muelleri (Table 2). None of the morphometric measurements were 
Table 2: The mean morphometric data obtained from all the collected Xenopus specimens.

\begin{tabular}{|c|c|c|c|c|c|c|c|c|c|c|c|c|c|}
\hline Area & Species & $n^{*}$ & $\begin{array}{l}\text { Mass } \\
\text { (g) }\end{array}$ & $\begin{array}{l}\text { Length } \\
(\mathrm{mm})\end{array}$ & $\begin{array}{l}\text { Head } \\
\text { width } \\
(\mathrm{mm})\end{array}$ & $\begin{array}{l}\text { Right } \\
\text { testes } \\
\text { length } \\
\left(\mathrm{mu}^{\star \star}\right) \\
\end{array}$ & $\begin{array}{l}\text { Right } \\
\text { testes } \\
\text { width } \\
\text { (mu) } \\
\end{array}$ & $\begin{array}{l}\text { Left testes } \\
\text { length } \\
(\mathrm{mu})\end{array}$ & $\begin{array}{l}\text { Left testes } \\
\text { width } \\
\text { (mu) }\end{array}$ & $\begin{array}{l}\text { Left liver } \\
\text { mass } \\
(\mathrm{g})\end{array}$ & $\begin{array}{l}\text { Heart } \\
\text { mass } \\
(\mathrm{g})\end{array}$ & $\begin{array}{l}\text { Fat body } \\
\text { mass } \\
(\mathrm{g})\end{array}$ & $\begin{array}{l}\text { Egg } \\
\text { mass } \\
(g)\end{array}$ \\
\hline \multicolumn{14}{|l|}{ Males } \\
\hline \multirow[t]{2}{*}{ Non DDT-sprayed } & X. muelleri & 3 & 47.1 & 65.3 & 23.7 & 86 & 34 & 89 & 32 & 0.72 & 0.17 & 0.82 & \\
\hline & $X$. laevis & 17 & 29.9 & 59.2 & 20.0 & 81 & 33 & 83 & 31 & 0.69 & 0.19 & 0.48 & \\
\hline \multirow[t]{2}{*}{ DDT-sprayed } & X. muelleri & 2 & 24.0 & 57.5 & 17.8 & 76 & 28 & 77 & 28 & 0.63 & 0.23 & 0.20 & \\
\hline & $X$. laevis & 9 & 30.4 & 60.3 & 20.2 & 86 & 29 & 91 & 28 & 0.77 & 0.18 & 0.51 & \\
\hline \multicolumn{14}{|l|}{ Females } \\
\hline \multirow[t]{2}{*}{ Non DDT-sprayed } & X. muelleri & 1 & 27.7 & 56.8 & 18.4 & & & & & 0.75 & 0.15 & 0.25 & 1.00 \\
\hline & X. laevis & 2 & 44.7 & 76.5 & 22.6 & & & & & 0.88 & 0.18 & 0.38 & 2.60 \\
\hline \multirow[t]{2}{*}{ DDT-sprayed } & X. muelleri & 2 & 32.9 & 64.2 & 20.1 & & & & & 1.05 & 0.13 & 0.38 & 2.40 \\
\hline & $X$. laevis & 2 & 37.4 & 68.0 & 20.5 & & & & & 1.70 & 0.40 & 0.43 & 3.08 \\
\hline
\end{tabular}

${ }^{*}$ Numbers of frogs collected not representative of sex distribution as number restrictions on permit only limited us to 50 individuals per species and a greater proportion of male frogs were selected for dissection

** Measurement units. 
significantly different between the two areas ( $p$ values ranged between $0.4379-0.8608$ ). However, the mean width of the right testes of males from the DDT-sprayed area was significantly $(p=0.0252)$ smaller than the mean of the right testes from the non-sprayed area. Additionally, measurements were compared between the left and right testes within the respective study areas. The right testes of the males from the DDT-sprayed area were significantly shorter $(p=0.0447)$ than their left testes. The widths of their right and left testes did not differ significantly. Neither the testes width nor the length differed significantly between right and left for the frogs from the reference area.

One $X$. laevis from the DDT-sprayed area had an extra left testis; this additional testis was smaller (length $\sim 16 \%$, width $60 \%$ ) than the primary left testis. The right testis appeared normal. None of the screened testes had any testicular oocytes.

\section{Discussion}

DDT-derived compounds had quantifiable concentrations of DDT and metabolites in frogs from both areas (Table 1). Despite the inability to compare statistically, generally higher concentrations in the DDT-sprayed areas were observed (Fig. 2). The DDTs are most likely derived from malaria control operations as there has never been commercial farming in the DDT-sprayed area, even when DDT use was still allowed for agriculture in SA. [DDT was banned in South Africa for agricultural purposes in 1976, with use of existing stocks prohibited after 1983 (Bouwman 2003)].

Due to the long distances between the sample sites and because the sites where they were collected are not directly connected by rivers or streams (Fig. 1), it is unlikely (but not impossible) that the DDT detected in frogs from the non-sprayed areas (all located higher up in the catchment) were due to frogs immigrating upstream and overland from the DDT-sprayed areas. Furthermore, many of the collection sites were isolated ponds, suggesting that the DDT came from local runoff. In a situation of colonisation after release in a temperate area (France), dispersal through water bodies was much faster than overland (Fouquet and Measey 2006). Since the ponds we collected the frogs were isolated and not connected to other streams, wetlands, or rivers, the residues in the reference area may therefore be a legacy from long-range transport from sprayed areas (as also noted by Fellers et al. 2004 and Sparling et al. 2001), past use, illegal current use, or a combination thereof. We have previously detected high concentrations of DDT in sparrow eggs from a town located outside the sprayed area (Bouwman et al. 2013) which we also ascribed to possible illegal DDT use.

Although the female frogs were generally larger than the males, their fat bodies were smaller than those of the males (Table 2). Females however, had higher concentrations of DDT metabolites (Fig. 2). We cannot explain this difference, as one would expect that egg deposition would reduce the overall load of DDT in the female. Concentrations of both $p, p^{\prime}-$ DDT and $o, p^{\prime}$-DDT could not be quantified in any frog, possibly due a relatively high LOQ. A lower analytical LOD could have improved the interpretability of the results. However, the percentage of $p, p^{\prime}$-DDT (of the sum of all DDTs measured) was also low (min $0.58 \%$, mean $0.97 \%$, max 1.2\%) in Grey Heron eggs from the same area (Bouwman et al. 2013), indicating a very low percentage of $p, p^{\prime}$-DDT in the aquatic environment. Jofré et al. (2008) also found no quantifiable $p, p^{\prime}$-DDT in frogs from Argentina. The reason why there is so little $p, p$-DDT in aquatic biota in areas where there is active application of this compound is not known. This could be due to the tropical nature of the area and that initial application is done as indoor residual spray (IRS) (van Dyk et al. 2010; Whitworth et al. 2014). The residues 
Table 3: Comparable mean DDT concentration data from elsewhere in the world

\begin{tabular}{|c|c|c|c|c|c|c|c|}
\hline Species & Locality & Situation & Organ & Year & $\begin{array}{l}\text { Total } \\
\text { ww) }\end{array}$ & DDT $\quad(\mathbf{n g} / \mathrm{g}$ & Reference \\
\hline Various & Rift Valley Lakes, Kenya & Farming area using DDT & Whole animal? & $1970-72$ & & $74-170^{*}$ & Lincer et al. 1981 \\
\hline Rana pipiens & Lake Erie, USA & Experimental application to a wetland & Whole animal & 1963 & & $2-550$ & Meeks et al. 1968 \\
\hline Rana catesbeiana & Lake Erie, USA & Experimental application to a wetland & Fat body & 1963 & & $470-1300$ & Meeks et al. 1968 \\
\hline Bufo gutturalis & Zimbabwe & Farming area using DDT & Whole animal & $<1987$ & & $30-3900$ & Table in Lambert, 2001 \\
\hline Ptychadena anchietae & Zimbabwe & Farming area using DDT & Whole animal & $<1989$ & & $1300-1500$ & Table in Lambert, 2001 \\
\hline Rana clamitans & Ontario, Canada & Farming area historically using DDT & Whole animal & $<1997$ & & $580-45000$ & Russel et al. 1997 \\
\hline Rana clamitans & Ontario, Canada & Farming area historically using DDT & Fat body & 1993 & & $50-3320$ & Harris et al. 1998 \\
\hline Rana clamitans & Michigan, USA & Forest and farmland & Whole animal & 1998 & & 1.24 & Gillilland et al. 2001 \\
\hline Rana ridibunda & Greece & Farming area historically using DDT & Whole animal & 1994 & & ND-30 & Loumbourdis, 1997 \\
\hline Rana muscosa & California, USA & Mountainous region, no DDT use & Whole animal & 1997 & & $17-46$ & Fellers et al. 2004 \\
\hline Rana perezi & Ebro, Spain & Coastal wetland, legacy DDT use & Whole larvae & $<2004$ & & $200-1613^{*}$ & Pastor et al. 2004 \\
\hline Rana perezi & Ebro, Spain & Coastal wetland, legacy DDT use & Whole animal & $<2004$ & & $135-1315^{*}$ & Pastor et al. 2004 \\
\hline Rhinella marina & Mexico & Industrial area & Fat body & 2006 & & $57-600$ & Gonzalez-Mille et al. 2013 \\
\hline Xenopus spp. & Limpopo South Africa & DDT-sprayed area & Fat body & 2009 & & $41-391$ & This study \\
\hline
\end{tabular}


from malaria control probably travel a longer route before reaching the aquatic environment than agriculturally applied DDT and therefore more $p, p^{\prime}$-DDT will break down to $p, p^{\prime}$-DDE.

Compared with DDT concentrations in fat bodies of frogs from elsewhere (Table 3), the present DDT concentrations were in the lower range. However, the species are different (none were Xenopus) and comparable lipid proportions are not available. One should also take care when interpreting Table 3, as the species, environment, dates, matrixes, and ecosystems differ widely. Overall, we conclude that Xenopus accumulate DDT from their environments, but that the concentrations in parts of the Limpopo province where we sampled were in the lower ranges compared to data from elsewhere. However, a more detailed aquatic assessment of the different trophic components of aquatic ecosystems will shed more light on the dynamics of DDT and other pollutants (Pastor et al. 2004).

Morphometric parameters offer a means of identifying ED effects in frogs since the process of metamorphosis and development is endocrine-mediated (Bögi et al. 2002; Jagnytsch et al. 2006). However, since the conditions of the different ponds differed and would affect growth (Harris et al. 1998), the differences in either sizes or masses (Table 2) cannot solely be attributed to DDTs. Endocrine disruption associated with DDTs has however, been detected in fish from the Luvuvhu River: intersex in male Mozambique Tilapia Oreochromus mossambicus was present throughout the Luvuvhu system (Barnhoorn et al. 2010).

One of the reported ED effects in laboratory exposure studies on amphibians, more specifically $X$. laevis, is masculinisation or feminisation, depending on the substance the animals are exposed to (Kloas and Lutz 2006; Cevasco et al. 2008). Kelce et al. (1995) found $p, p^{\prime}-\mathrm{DDE}$ to be a potent androgen receptor antagonist. Even though the $p, p^{\prime}-\mathrm{DDE}$ isomer concentrations in the males from the DDT-sprayed area was higher than the nonsprayed area (Fig. 2), no indication of feminisation (testicular oocytes) was found. The present study found a significantly narrower right testis in $X$. laevis from the DDT-sprayed area compared to the left testis (means 29 mu vs. $33 \mathrm{mu}$; Table 2). The mean length of the testes did not differ significantly between groups. Literature on asymmetry in frogs is scarce. A shorter testis length in male $X$. laevis exposed to ethinylestradiol and an increased length when exposed to methyldihydrotestosterone was found by Cevasco et al. (2008). Exposure to methoxychlor, an estrogenic chemical, resulted in reduced size and misshapen right testes of $X$. tropicalis (Fort et al. 2004). Reviews that considered abnormal testicular morphology rarely referred to asymmetry (Lutz et al. 2008; Mann et al. 2009; Rohr and McCoy 2010; Solomon et al. 2008; van den Kraak et al. 2014), but do refer to discontinuous gonads (or segmental aplasia).

We do not know the mechanism that may cause the observed asymmetry between left and right testes in the frogs. Symmetrical development of testis morphology may be mediated by endocrine systems, but we could not find direct evidence for this in the literature. Internal somatic development (especially of the circulatory system) during embryogenesis in the frog is not symmetrical (Nieuwkoop and Faber 1967), but there is eventual symmetry of organs such as kidneys and testes. Fluctuating asymmetry is the deviation from the norm between the two sides of a bilaterally symmetrical organism (Møller and Swaddle 1997) and may be caused by environmental stress during development. Fluctuating asymmetry is also an indication of the quality of the individual. Persistent organic pollutants have been associated with increased asymmetry in wing feathers of gulls (Bustnes et al. 2007). Fluctuating asymmetry in wing length, tarsus length and head length of cormorants were associated with endocrine variables (thyroid hormones, retinol and tocopherol) and persistent organic pollutants (Jenssen et al. 2010). The asymmetry in the 
testes of the frogs from the DDT-spayed area, as well as a single case of an extra discontinuous left testis is therefore suggestive, but not conclusive, of endocrine disruption, possibly from DDT. More studies therefore, need to be conducted.

As a consequence of chronic long-term exposure, frogs may develop 'resistance' to DDT as suggested by Boyd et al. (1963). In Mississippi, Boyd et al. (1963) found that frogs from areas where DDT has been used for crop protection had lower mortalities when exposed to DDT than frogs from reference areas. It is not known whether this is also the case in the present situation where DDT has been applied for malaria control since the late 1940's. Exposure to DDT is likely to affect survival and fitness of frogs in various ways. DDT caused behavioural changes in Rana temporaria and Bufo bufo tadpoles in a laboratory study (Cooke 1970). In a laboratory study, Cooke (1973) found that chronic exposure to DDT may have caused kinks in the tails of $R$. temporaria tadpoles and induced hyperactivity (characterised as "frantic"). Deformities and changes in behaviour like this may expose the tadpoles to greater predation (Cooke 1973). Based on museum specimens from the USA, intersex in cricket frogs Acris crepitans was the highest between 1946-1959 during the greatest manufacture of DDT and PCB, and declined afterwards (Reeder et al. 2005). More effects are discussed by Carey and Bryant (1995), Lutz and Kloas (1999), and Kloas et al. (1999).

\section{Conclusion}

As expected, DDTs were present in quantifiable concentrations in frogs from a DDTsprayed area, but also from non-sprayed areas. We postulate a variety of sources including DDT from malaria control and long-range transport. The presence of quantifiable DDTderived compounds may explain its bio-accumulation in higher trophic animals such as the Grey Heron. Endocrine disruption due to DDT may have affected testicular morphology, but no testicular oocytes were found. Although only a few frogs were found after many hours of trapping, our findings raises concern about frog numbers and general health of frogs in the study area. Behavioural effects of DDT in frogs, although not studied here, may also influence predation pressure. Taken together with associations of DDT with other impacts such as intersex in male Mozambique Tilapia (Barnhoorn et al. 2010), urogenital malformations in baby boys (Bornman et al. 2010), eggshell thinning in birds from this area (Bouwman et al. 2013; Steyn et al. 2015), and the highest ever recorded concentrations of DDT in fish from South Africa, downstream of the same area inside the Kruger National Park (Gerber et al. 2016), our preliminary findings confirm the caution expressed by Ellis et al. (1944) more than 80 years ago, and add urgency to the need to reduce and eventually move away from DDT in malaria control, safely and sustainably.

Acknowledgements We thank JP Huisamen, Ben van der Waal, and Cecila Kwinda. Funding was provided by the South African Water Research Commission (WRC) and the National Research Foundation (NRF). Opinions expressed and conclusions arrived at are those of the authors, and are not necessarily to be attributed to the WRC or NRF. The authors declare they have no actual or potential competing financial interests. 


\section{References}

Aneck-Hahn, N.H., Schulenburg, G.W., Bornman, M.S., Farias, P., De Jager, C., 2007. Impaired semen quality associated with environmental DDT exposure in young men living in a malaria area in the Limpopo Province, South Africa. J. Androl. 28, 423-434

Barnhoorn, I.E., Bornman, M.S., Jansen van Rensburg, C., Bouwman, H., 2009. DDT residues in water, sediment, domestic and indigenous biota from a currently DDT-sprayed area. Chemosphere. 77:1236-1241.

Barnhoorn IEJ, van Dyk JC, Pieterse GM, Bornman MS. 2010. Intersex in feral indigenous freshwater Oreochromis mossambicus, from various parts of the Luvuvhu River, Limpopo Province, South Africa. Ecotoxicol. Environ. Saf. 73:1537-1542.

Blaustein, A.R., Han, B.A., Relyea, R.A., Johnson, P.T., Buck, J.C., Gervasi, S.S., Kats, L.B., 2011. The complexity of amphibian population declines: understanding the role of cofactors in driving amphibian losses. Ann. N. Y. Acad. Sci. 1223, 108-119.

Bögi, C., Levy, G., Lutz, I., Kloas, W., 2002., Functional genomics and sexual differentiation in amphibians. Comp. Biochem. Physiol. B. Biochem. Mol. Biol. 133, 559-570.

Bordet, F., Inthavong, D., Fremy, J-M., 2002., Interlaboratory study of a multiresidue gas chromatographic method for determination of organochlorine and pyrethroid pesticides and polychlorobiphenyls in milk, fish, eggs, and beef fat. J. AOAC Int. 85, 1398-1409.

Bornman, R., de Jager, C., Worku, Z., Farias, P., Reif, S., 2010. DDT and urogenital malformations in newborn boys in a malarial area. BJU Int. 106, 405-410.

Bouwman, H., 2003. POPs in Southern Africa. The Handbook Environmental Chemistry, Vol. 3, Part 0, 297-320.

Bouwman, H., Coetzee, A., Schutte, C., 1990. Environmental and health implications of DDT-contaminated fish from the Pongolo Flood Plain. Afr. Zool. 104, 75-286.

Bouwman, H., Sereda, B., Meinhardt, H., 2006. Simultaneous presence of DDT and pyrethroid residues in human breast milk from a malaria endemic area in South Africa. Environ. Pollut. 144, 902-917.

Bouwman, H., Viljoen, I.M., Quinn, L.P., Polder, A., 2013. Halogenated pollutants terrestrial and aquatic bird eggs, Converging patterns of pollutant profiles, and impacts and risks from high levels. Environ. Res. 126, 240-253.

Boyd, C.E., Vinson, B.S., Ferguson, D.E., 1963. Possible DDT resistance in two species of frogs. Copeia. 2, 426-429.

Bustnes, J.O., Folstad, I., Erikstad, K.E., Fjeld, M., Miland, Ø., Skaare, J.U., 2002. Blood concentrations of organochlorine pollutants and wing feather asymmetry in glaucous gull. Funct. Ecol. 16, 617-22.

Carey, C., Bryant, C.J., 1995. Possible interrelations among environmental toxicants, amphibian development, and decline of amphibian populations. Environ. Health. Perspect. 103, 13.

Cevasco, A., Urbatzka, R., Bottero, S., Massari, A., Pedemonte, F., Kloas, W., Mandich, A., 2008. Endocrine disrupting chemicals (EDC) with (anti)estrogenic and (anti)androgenic modes of action affecting reproductive biology of Xenopus laevis: II. Effects on gonad histomorphology. Comp. Biochem. Physiol. C. Toxicol. Pharmacol.147, 241-251.

Collins, J.P., Storfer., A. 2003. Global amphibian declines: Sorting the hypotheses. Divers. Distrib. 9, 89-98.

Cooke, A.S., 1970. The effects of DDT, dieldrin and 2,4-D on amphibian spawn and tadpoles. Environ. Pollut. 3, 51-68. 
Cooke, A.S., 1973. Response of Rana temporaria tadpoles to chronic doses of pp'-DDT. Copeia. 4, 647-652.

Ellis, M.M., Westfal, B.A., Ellis, M.D., 1944. Toxicity of dichloro-diphenyl-trichloroethane (DDT) to goldfish and frogs. Science. 2604, 477.

Fouquet, A., Measy, G.J., 2006. Plotting the course of an African clawed frog invasion in western France. Anim. Biol. 56, 95-102.

Fellers, G.M., McConnell, L.L., Pratt, D., Datta, S., 2004. Pesticides in Mountain Yellowlegged Frogs (Rana muscosa) from the Sierra Nevada Mountains of California, USA. Environ. Toxicol. Chem. 23, 2170-2177.

Fort, D.J., Thomas, J.H., Rogers, R.L., Noll, A., Spaulding, C.D., Guiney, P.D., Weeks, J.A., 2004. Evaluation of the developmental and reproductive toxicity of methoxichlor using an anuran (Xenopus tropicalis) chronic exposure model. Toxicol. Sci. 81, 443-453.

Gerber, R., Smit, N.J., van Vuuren, J.H.J., Nakayama, S.M.M., Yohannes, Y.B., Ikenaka, Y., Ishizuka, M., Wepener, V., 2016. Bioaccumulation and human health risk assessment of DDT and other organochlorine pesticides in an apex aquatic predator from a premier conservation area. Sci. Total Environ. 550, 522-533.

Gaspar, F.W., Chevnier, J., Bornman, R., Crause, M., Obida, M., Barr, D.B., Bradman, A., Bouwman, H., Eskenazi, B., 2015. Undisturbed dust as a metric of long-term indoor insecticide exposure: Residential DDT contamination from indoor residual spraying and its association with serum levels in the VHEMBE cohort. Environ. Int. 85, 163-167.

Gillilland, C.D., Summer, C.L., Gillilland, M., Kannan, K., Villeneuve, D.L., Coady, K.K., Muzzall, P., Mehne, C., Giesy, J.P., 2001. Organochlorine insecticides, polychlorinated biphenyls, and metals in water, sediment and Green Frogs from South Western Michigan. Chemosphere. 44, 27-339.

Gonzalez-Mille, D.J., Espinosa-Eyes, G., Rivero-Pérez, N.E., Trejo-Acevedo, A., NavaMontes, A.D., Ilizaliturri-Hernández, C.A., 2013. Persistent organochlorine pollutants (POPs) and DNA damage in Giant Toads (Rhinella marina) from an industrial area at Coatzacoalos, Mexico. Water Air Soil Pollut. 224, 178.

Harris, M.L., Bishop, C.A., Struger, J., van den Heuvel, M.R., van der Kraak, G.J., Dixon, D.G., Ripley, B., Bogart, J.P., 1998. The functional integrity of Northern Leopard Frog (Rana pipiens) and Green Frog (Rana clamitans) populations in orchard wetlands. I. Genetics, physiology, and biochemistry of breeding adults and young-of-the-year. Environ. Toxicol. Chem. 17, 1338-1350.

Hockey, P., Dean, W.R.J, Ryan, P., 2005. Roberts birds of southern Africa. Trustees of the John Voelcker Bird Book Fund, Cape Town. South Africa.

Jagnytsch, O., Opitz, R., Lutz, I., Kloas, W., 2006. Effects of tetrabromobisphenol A on larval development and thyroid hormone-regulated biomarkers of the amphibian Xenopus laevis. Environ. Res. 101, 340-348.

Jenssen, B.M., Aarnes, J.B., Murvoll, K-M., Hertzke, D., Nygård, T., 2010. Fluctuating wing asymmetry and hepatic concentrations of persistent organic pollutants are associated in European shag (Phalacrocorax aristotelis) chicks. Sci. Total. Environ. 408, 578-585.

Jofré, M.B., Antón, R.I., Caviedes-Vidal, E., 2008. Organochlorine contamination in anuran amphibians of an artificial lake in the semiarid Midwest of Argentina. Arch. Environ. Con. Tox. 55, 471-480.

Jooste, A.M., du Preez, L.H., Carr, J,A., Giesy, J.P., Gross, T.S., Kendall, R.J., Smith, E.E., van der Kraak, G.L., Solomon, K.R., 2005. Gonadal development of larval male Xenopus laevis exposed to Atrazine in outdoor microcosms. Environ. Sci. Technol. 39, 5255-5261. 
Kelce, W.R., Stone, C.R., Laws, S.C., Grey, L.E., Kemppainen, J.A., Wilsom, E.M., 1995. Persistent DDT metabolite $p, p^{\prime}-\mathrm{DDE}$ is a potent androgen receptor antagonist. Nature. 375, 581-585.

Kloas, W., Lutz, I., 2006. Amphibians as model to study endocrine disrupters. J. Chromatogr. A. $1130,16-27$.

Kloas, W., Lutz, I., Einspanier, R., 1999. Amphibians as a model to study endocrine disruptors: II. Estrogenic activity of environmental chemicals in vitro and in vivo. Sci. Total. Environ. 225, 59-68.

Lambert, M., 1997. Environmental effects of heavy spillage from a destroyed pesticide store near Hargeisa (Somaliland) assessed during the dry season, using reptiles and amphibians as bioindicators. Arch. Environ. Con. Tox. 32, 80-93.

Lambert, M.R.K., 2001. Residue loads in amphibians used as biomarkers of pesticide levels entering food chains in Sub-Saharan Africa. Afr. J. Herpetol. 50, 105-114.

Laporte, P., 1982. Organochlorine residues and eggshell measurements of Great Blue Heron eggs from Quebec. Colon. Waterbird. 5, 95-103.

Lincer, J.L., Zalkind, D., Brown, L.H., Hopcraft, J. 1981. Organochlorine residues in Kenya's Rift Valley lakes. J. Appl. Ecol. 18, 157-171.

Loumbourdis, N.S., 1997. Organochlorine pesticides in the frog Rana ridibunda from the fresh waters of northern Greece. Toxicol. Environ. Chem. 63, 63-69.

Lutz, I., Kloas, W., 1999. Amphibians as a model to study endocrine disruptors: I. Environmental pollution and estrogen receptor binding. Sci. Total. Environ. 225, 49-57.

Lutz, I., Kloas, W., Springer, T.A., Holden, L.R., Wolf, J.C., Kreuger, H.O., Hosmer, A.J., 2008. Development, standardization and refinement of procedures for evaluating effects of endocrine active compounds on development and sexual differentiation of Xenopus laevis. Anal. Bioanal. Chem. 390, 2031-2048.

Mann, R.M., Hyne, R.V., Choung, C.B., Wilson, S.P., 2009. Amphibians and agricultural chemicals: Review of the risks in a complex environment. Environ. Pollut. 157, 29032927.

Meeks, R.L., 1968. The accumulation of ${ }^{36} \mathrm{Cl}$ ring-labelled DDT in a freshwater marsh. J. Wildlife Manage. 32, 376-398.

Møller, A.P., Swaddle, J.P., 1997. Asymmetry, developmental stability, and evolution. Oxford, UK: Oxford University Press.

Nieuwkoop, P.D., Faber, J., 1967. Normal table of Xenopus laevis (Daudin). 2nd ED. North Holland publishing company. Amsterdam. Holland.

Pastor, D., Sanpera, C., González-Solís, J., Ruiz, X., Albaigés, J., 2004. Factors affecting the organochlorine pollutant load in biota of a rice field ecosystem (Ebro Delta, NE Spain). Chemosphere 55, 567-576.

Reeder, A.L., Ruiz, M.O., Pessier, A., Brown, L.E., Levengood, J.M., Phillips, C.A., Wheeler, M.B., Warner, R.E., Beasley, V.R., 2005. Intersexuality and the cricket frog decline: Historic and geographic trends. Environ. Health Persp. 113, 261-265.

Rohr, J.R., McCoy, K.A., 2010. A qualitative meta-analysis reveals consistent effects of atrazine on freshwater fish and amphibians. Environ. Health Persp. 118, 20-32.

Russel, R.W., Gillian, K.A., Haffner, G.D., 1997. Polychlorinated biphenyls and chlorinated pesticides in southern Ontario, Canada, Green Frogs. Environ. Toxicol. Chem. 16, 22582263.

Sereda, B., Bouwman, H., Kylin, H., 2009. Comparing water, bovine milk, and indoor residual spraying as possible sources of DDT and pyrethroid residues in breast milk. J. Toxicol. Env. Heal. A. 72, 842-851. 
Sparling, D.W., Fellers, G.M., McConnell, L.L., 2001. Pesticides and amphibian population declines in California, USA. Environ. Toxicol. Chem. 20, 1591-1595.

Solomon, K.R., Carr, J.A., du Preez, L.H., Giesy, J.P., Kendall, R.J., Smith, E.E., van der Kraak, G.J., 2008. Effects of atrazine on fish, amphibians, and aquatic reptiles: A critical review. Crit. Rev. Toxicol. 38, 721-772.

Steyn, L., Bouwman, H., Maina, J.N., 205. The effects of DDT and its metabolites on the structure of the shells of the eggs of the House Sparrow, Passer domesticus: A morphometric study. Seventh International Toxicology Symposium in Africa; August 2015, Johannesburg, South Africa. PP 98-99.

Van den Kraak, G.J., Hosmer, A.J., Hanson, M.L., Kloas, W., Solomon, K.R., 2014. Effects of atrazine in fish, amphibians, and reptiles: An analysis based on quantitative weight of evidence. Crit. Rev. Toxicol. 44, 1-66.

van Dyk, J.C., Bouwman, H., Barnhoorn, I.E., Bornman, M.S., 2010. DDT contamination from indoor residual spraying for malaria control. Sci. Total Environ. 408, 2745-2752.

Weldon, C., 2005. Chytridiomycosis, an emerging infectious disease of amphibians in South Africa. Unpublished MSc thesis, North-West University. Potchefstroom, South Africa.

Whitworth, K., Bornman, R.M.S., Archer, J., Kudumu, M.O., Travlos, G.S., Wilson, R.E., Longnecjer, M.P., 2014. Predictors of plasma DDT and DDE concentrations among women exposed to indoor residual spraying for malaria control in the South African Study of Women and Babies (SOWB). Environ. Health Persp. 122, 545-552. 